35 Jones E, Vermaas RH, McCartney $\mathrm{H}$, Beech $\mathrm{C}$, Palmer I, Hyams $\mathrm{K}$, et al. Flashbacks and post-traumatic stress disorder: the genesis of a 20th-century diagnosis Br J Psychiatry 2003; 182: 158-63.

36 De Silva P. The tsunami and its aftermath in Sri Lanka: explorations of a Buddhist perspective. Int Rev Psychiatry 2006; 18: 281-7.

37 Rajkumar AP, Mohan TSP, Tharyan P. Lessons from the 2004 Asian tsunami: epidemiological and nosological debates in the diagnosis of post-traumatic stress disorder in non-Western post-disaster communities. Int J Soc Psychiatry 2013; 59: 123-9.

$38 \mathrm{Mol} \mathrm{SSL}$, Arntz A, Metsemakers JFM, Dinant GJ, Vilters-van Montfort PAP, Knottnerus JA. Symptoms of post-traumatic stress disorder after non-traumatic events: evidence from an open population study. Br J Psychiatry 2005; 186: 494-9.
39 Scott MJ, Stradling SG. Post-traumatic stress disorder without the trauma. Br J Clin Psychol 1994; 33: 71-4.

40 Hanwella R, De Silva V. Mental health of Special Forces personnel deployed in battle. Soc Psychiatry Psychiatr Epidemiol 2012; 47: 1343-51.

41 Hotopf M, Wessely S. Can epidemiology clear the fog of war? Lessons from the 1990-91 Gulf War. Int J Epidemiol 2005; 34: 791-800.

42 Knudsen AK, Hotopf M, Skogen JC, Overland S, Mykletun A. The health status of nonparticipants in a population-based health study: the Hordaland Health Study. Am J Epidemiol 2010; 172: 1306-14.

\title{
reflection
}

\section{The crooked wisdom of Francis Bacon's Essays}

\section{Alistair Stewart}

'Good advice for Satan's kingdom' - this was William Blake's opinion of the Essays of Francis Bacon (1561-1626), a man of wealth and taste who was sometime Chancellor to King James I of England, and an intellectual godfather to the future Royal Society. In his essays, Bacon dealt with many things, including friendship, travel and gardens, but his focus was particularly on statecraft, and what would now be called 'man-management'.

In a concentrated style, he offers counsel to those in powerful positions:

'The vices of authority are chiefly four: delays, corruption, roughness and facility. For delays; give easy access; keep times appointed; go through with that which is in hand; and interlace not business but of necessity ... For roughness, it is a needless cause of discontent: severity breedeth fear, but roughness breedeth hate. Even reproofs from authority ought to be grave, and not taunting ...'

He describes how to get things done, in words which should resonate with any doctor who finds themselves sitting on a committee:

'There be three parts of business: the preparation, the debate or examination, and the perfection. Whereof, if you look for dispatch, let the middle only be the work of many, and the first and last the work of few.'

With respect to manipulation and control for political purposes, he is brutally frank:

'If you would work any man, you must either know his nature and fashions, and so lead him; or his ends, and so persuade

him; or his weakness and disadvantages, and so awe him; or those that have interest in him, and so govern him.'

He offers examples of how to deceive and defraud which have a familiar ring:

'In things that a man would not be seen in himself, it is a point of cunning to borrow the name of the world; as to say, The world says, or, There is a speech abroad.'

At the same time he suggests how we can guard against those who seek to manipulate us:

'In dealing with cunning persons, we must ever consider their ends, to interpret their speeches; and it is good to say little to them, and that which they least look for.'

On one recent estimate, the leadership training industry is now worth $£ 30$ billion worldwide. Health service organisations have a huge appetite for its products, which contain a large amount of recycled and context-free platitudes. By contrast, whatever their moral status, Francis Bacon's observations from the chambers, passages and staircases of 17th-century London have a refreshing directness.

Leadership is always exercised for a particular purpose. The kind of leadership we need is determined by the direction in which we want to travel. Especially in a field as politically charged as the provision of healthcare, some awareness of the dark side of political manoeuvring is essential, just as it was to Bacon and his contemporaries. As he wrote elsewhere,

'It is not possible to join serpentine wisdom with columbine innocency, except men know exactly all the conditions of the serpent.' 